\title{
APRESENTAÇÃO - DOSSIÊ TEMÁTICO: ENSINO MÉDIO - PASSOS E IMPASSES NA ATUALIDADE
}

\author{
Gaudêncio Frigotto ${ }^{1}$ \\ Marise Ramos
}

\begin{abstract}
A Revista e-Mosaicos, nesta $19^{a}$ edição, optou por um Dossiê Temático que trata, especialmente, do ensino médio nas suas diferentes modalidades e em diferentes aspectos. O número de artigos enviados expressa o quanto o tema do ensino médio assume centralidade no debate da educação básica. As razões históricas de sua negação sistemática para grande parte dos jovens inscrevem-se no fato de a educação básica pública, universal, gratuita, laica e unitária nunca ter sido prioridade da classe dominante brasileira. Ao contrário, sua negação se constitui numa escolha. Sendo assim, em todos os momentos da história da educação brasileira em que as lutas da classe trabalhadora por este direito conseguem lograr algum avanço, a elite reage com políticas regressivas.

O cinismo disto está na forma dissimulada dessa reação. No plano do discurso, Anísio Teixeira expressou essa dissimulação ao mostrar que os valores proclamados em defesa da educação não eram reais. $E$ isto vale para os avanços conquistados na legislação pelas lutas das instituições e organizações científicas, culturais, sindicatos e movimentos sociais.
\end{abstract}

A Constituição Federal de 1988 é um exemplo do que estamos assinalando. A correlação de forças no momento de sua aprovação limitou a obrigatoriedade do ensino médio a um projeto que deveria ser progressivamente realizado. Mesmo o seu reconhecimento como última etapa da educação básica pela Lei de Diretrizes e Bases da Educação Nacional aprovada somente em 1996 - e em uma versão minimalista interessante ao pensamento conservador - não foi suficiente para que o ensino médio se tornasse obrigatório. Uma aproximação desse objetivo se fez mediante a Emenda Constitucional no 59, de 2009, quando a educação é tornada obrigatória e gratuita dos quatro aos 17 anos de idade. No entanto, como a obrigatoriedade foi definida com base na faixa etária e não nos anos de escolaridade, o ensino médio continua a ser, na prática, um projeto para a completude da educação básica. Isto porque um único ano de defasagem idade-série exclui o estudante dessa determinação, o que acaba por ajudar a manter a Educação de Jovens e Adultos como uma modalidade da educação básica destinada àqueles que não a concluíram em idade considerada apropriada.

Esse histórico, lamentavelmente, converge com a conclusão de Florestan

\footnotetext{
${ }^{1}$ Professor Associado na Universidade do Estado do Rio de Janeiro (UERJ) e Professor Titular (aposentado) na Universidade Federal Fluminense (UFF).

2 Professora Associada na Universidade do Estado do Rio de Janeiro (UERJ) e Especialista em Ciência, Tecnologia, Produção e Inovação em Saúde Pública da Fundação Oswaldo Cruz (FIOCRUZ).
} 
Fernandes - histórico batalhador pela educação pública e batalhador como deputado federal na elaboração da Constituição de 1988 -, logo que a mesma foi proclamada, de que a educação, de fato, continuava sendo tema de segunda categoria na agenda nacional.

Mesmo as conquistas parciais asseguradas nas Cartas Magnas, naquilo que confronta interesses ou concepções das forças conservadoras, acabam sendo contidas por mecanismos protelatórios, como bem analisa Dermeval Saviani, ou, paulatinamente descaracterizadas no processo de sua regulamentação. É o que nos mostram os longos anos de demora em se aprovar a LDB de 1961, que responderia à determinação da Constituição de 1946; e a LDB de 1996, que atenderia à Constituição de 1988. O mesmo testemunhamos na aprovação dos dois últimos Planos Nacionais de Educação, em cujos processos intelectuais orgânicos e representantes políticos da classe dominante atuaram de forma ampla e sistematicamente organizada. Esses são exemplos emblemáticos da estratégia de se protelar as regulamentações que carregavam contradições virtuosas em benefício da classe trabalhadora, descaracterizando-se, assim, os poucos avanços conquistados pela classe dominada.

A despeito desses mecanismos, o que se observa nas alterações que essa etapa da educação básica tem sofrido, desde a década de 1950, ligam-se às disputas em torno de sua concepção, finalidade e organização, sendo que essas se alteram dependendo do bloco de forças que assumem os governos Federal e estaduais. 0 sociólogo Luiz Antônio Cunha, em suas análises, define essas mudanças como políticas zig-zag, pra mostrar que a cada troca de governo se estabelecem rupturas ou descontinuidades,

A disputa de concepção, finalidade e de organização do ensino médio reflete as disputas nas relações sociais e a natureza e o poder da classe dominante brasileira. Uma ampla literatura que analisa o projeto societário dessa classe destaca seu DNA colonizador e escravista, sem compromisso com a nação e de postura de desprezo com o povo e seus direitos de educação, saúde e cultura. Uma classe que interrompe conquistas populares mediante ditaduras ou golpes institucionais; processos esses que nos fazem viver permanentemente em "estado de exceção".

$\mathrm{O}$ que acabamos de sinalizar se materializou com a ditadura empresarial militar de 1964 em face dos avanços na sociedade e na educação e cultura após a Ditadura de Getúlio Vargas, incluindo o ensino médio, à época denominado de ensino secundário. Sob a vigia de organismos internacionais e hegemonia dos Estados Unidos, a ideologia do capital humano orientou a educação brasileira da pré escola à pós graduação, em especial as mudanças na educação protagonizadas pela ditadura. O mesmo ocorre recentemente, com a contrarreforma do ensino médio, efetivada a partir do golpe jurídico-midiático-empresarial que retirou a Presidenta Dilma Rousseff do cargo para o qual fora legitimamente eleita.

Derrotada a ditadura civil-militar, a sociedade brasileira buscou reconstruir o Estado democrático de direito, tendo na Constituição de 1988 a expressão do equilíbrio de forças em disputa na sociedade e na educação. No período constituinte 
e depois na LDB e Plano Nacional de Educação a disputa entre a manutenção da escola dual e a diferenciação em seu interior ou em confronto com o projeto de escola unitária e a concepção que a orienta, como nunca, foi explícita. Os avanços conceituais, ético-políticos e práticos desse período, possibilitados pela sociedade civil organizada que reunira forças numa guerra de posição ao longo dos anos de chumbo, são destroçados pelas políticas neoliberais da década de 1990 . No âmbito do ensino médio, o Decreto $n^{\circ} 2.208 / 97$, referido em vários artigos deste dossiê, materializa a afirmação da dualidade e de uma concepção pragmática e fragmentária de educação. A concepção, nessa mudança, é ainda mais regressiva, pois pautada pela ideologia das competências, da empregabilidade e do empreendedorismo.

As forças sociais que combateram a ditadura e a década de governo neoliberal elegeram em 2003 um governo cuja agenda proposta por essas forças demandava confrontar as teses neoliberais e retomar reformas estruturais e políticas sociais. As reformas estruturais encontraram uma barreira interna e externa articuladas dentro de um bloco histórico comandado pelo capital. Nesse terreno, por essa razão e, também por perda dessa base social, não houve rupturas.

Todavia, foram as políticas de expansão das universidades públicas, sobretudo da expansão e interiorização dos Institutos Federais de Educação, Ciência e Tecnologia (IFs), as políticas de inclusão de índios, quilombolas, ribeirinhos e alunos das escolas publicas e o não alinhamento subordinado aos Estados Unidos, que levaram a um novo golpe de estado consumado em agosto de 2016. Em relação ao ensino médio, o que incomodou as forças conservadoras foi a revogação do Decreto $n^{\circ} 2.208 / 1997$ que havia chancelado a dualidade, e a aprovação do Decreto $n^{0}$ $5.154 / 2004$, que facultava o ensino médio integrado tendo como base a relação entre trabalho, ciência e cultura, tendo o trabalho como princípio educativo.

O campo de educação é o que melhor explicita o quanto o golpe foi montado pelas forças econômicas e políticas da década de 1990, sobretudo as que se articularam ao longo dos oito anos do governo de Fernando Henrique Cardoso e seu Ministro Paulo Renato de Souza. Não por acaso a pessoa chave do Ministério da Educação na gestão de Paulo Renato, Maria Helena Guimarães de Castro, foi também a protagonista da contarreforma do ensino médio aprovada rapidamente no período golpista, primeiro por meio da Medida Provisória no 746/2016, transformada na Lei no 13.415/2017. Essa contrarreforma liquidou com o ensino médio como última etapa da educação básica, e com qualquer projeto que lutava por sua universalidade e unitariedade. Ataca frontalmente a concepção de formação integrada e regride aos aspectos mais discriminatórios de legislações passadas, superados com muita luta, a exemplo da fragmentação do ensino da década de 1940; da dualidade entre formação propedêutica e profissionalizante da década de 1970; da dissociação da entre formação básica e profissional e o pragmatismo das competências dos anos de 1990.

A ironia da história é que as forças de centro-direita e de direita que urdiram o golpe foram mais derrotadas eleitoralmente e entregaram o governo a um bloco de forças de extrema direita. Um governo que no campo da educação se pauta pela 
pedagogia do ódio ao pensamento crítico e, pautado pela ideologia da meritocracia, busca anular as conquistas de acesso à educação das comunidades indígenas, quilombolas ribeirinhos e alunos pobres em escolas e universidades públicas.

Mediante o fundamentalismo religioso, esse grupo faz o conhecimento retroceder à idade média, subordinando a ciência à crença; e utilizando o medo, estratégias de denúncias e perseguição para impor seu pensamento, com o intuito de travar uma "guerra cultural". Enquanto isso, a política econômica segue dilapidando e entregando violentamente o patrimônio público aos interesses do capital internacional, configurando um tipo de capitalismo dependente muito mais explícito e arbitrário dirigido pelas frações mais retrógradas da burguesia brasileira, o que coloca em cheque até mesmo qualquer conceito ou princípio de "nação". Um cenário, pois, de profunda regressão social e educacional.

O exposto até aqui visa situar o leitor no âmbito deste Dossiê Temático sobre ensino médio. Nenhum dos artigos se refere às mudanças que o bloco de ultra direita está buscando implantar na educação e na cultura a partir de 2019 . O conjunto deles, todavia, aborda de forma crítica aspectos do que tem sido a disputa no ensino médio.

O primeiro artigo, de caráter mais geral, traz uma análise das políticas públicas em educação no marco da internacionalização no contexto da regressão social marcada pelo neoliberalismo. 0 segundo, também de caráter geral, resulta de uma pesquisa sobre a representação de estudantes de ensino médio público e a relação com a comunidade. Os demais tratam de aspectos específicos do ensino médio.

Com efeito, o terceiro artigo mostra a crescente inserção de jovens na EJA, enfatizando a relação entre trabalho e educação. $O$ que segue analisa a dualidade e as contradições na educação profissional, questão esta atualizada pelo quinto texto, mediante análise da relação entre o Decreto n 2.208/1997 e a Lei no 13.415/2017, assim como sétimo, que analisa a mesma lei, corroborando o que indicamos acima. O sexto texto efetiva uma crítica sobre o caráter reducionista do que se denominou do "novo ensino médio de tempo integral".

O oitavo e nono textos trazem a dimensão de diferentes práticas e experiências que explicitam a ação ativa de instituições ou grupos no ensino médio e profissional. Enquanto o oitavo demonstra que Programa Brasil Profissionalizado permitiu incluir e expandir o ensino médio integrado na rede do Estado do Ceará, o nono texto mostra como o PROEJA do IFSP resiste às mudanças curriculares efetivadas após o golpe de estado de 2016. Por fim, os três últimos textos trazem práticas curriculares inovadoras no ensino médio.

Certamente a leitura dos textos ajudará os leitores a entender a necessidade não apenas da crítica aos retrocessos na educação em geral e no ensino médio em particular, mas também de uma resistência ativa no plano da ação política. 